\title{
HUNTING TOURISM DEVELOPMENT IN THE TUZLA CANTON
}

\author{
Senada Nezirović ${ }^{1}$
}

\begin{abstract}
The research of the development of hunting tourism in the Tuzla Canton is basically reduced to the need of establishing effective coordination of tourism development at the cantonal level as well as the region of north-eastern Bosnia, connecting tourist destinations on a number of common development issues, and achieving higher levels of overall economic development. The Tuzla Canton has the natural resources that can be used throughout the year. The area is characterized by a pleasant climate and excellent biogeographic characteristics. The mountains have preserved flora and fauna. In the forests of Ozren, Trebavac, Majevica, Konjuh, Javornik and along rivers' valleys, there are wild game, which is an important resource and a base for hunting tourism. The hunting grounds in the Tuzla Canton are divided into social and state hunting grounds. The aim of this paper is to show the possibilities for the development of hunting tourism as a factor of economic development of the Tuzla Canton and surroundings. Methodology of the research demanded field and cabinet work. Besides the literature, for the development of this paper, there were used planning documents, maps, field drawings, and statistical indicators that were processed by modern geographic methods including also GIS technology. By identifying the entire area, rich hunting grounds in the area of the Tuzla Canton were introduced, whereat the guidelines were given in the further development of hunting tourism and the creation of the position of the Tuzla Canton as a significant tourist destination.
\end{abstract}

Key words: hunting, development, the Tuzla Canton

\section{INTRODUCTION}

The Tuzla Canton is located in the northeastern part of Bosnia and Herzegovina. It is located within the geographical coordinates $44^{\circ} 10^{\prime}$ and $44^{\circ} 55^{\prime}$ north latitude and $18^{\circ} 8^{\prime}$ and $19^{\circ} 3^{\prime}$ eastern longitude. It covers an area of $2.652 \mathrm{~km}^{2}$, where estimated 499.099 inhabitants live. There are 13 municipalities within the Tuzla Canton. It has a favorable geographical position, its openness to the Pannonian Plain and transport links with the Adriatic coast are a very important element for use of the resources of the area. The territory of the Tuzla Canton is rich with a variety of plant and animal species. On the slopes of Majevica, its habitat has a bear, wolf, doe deer, buck deer, wild boar, fox and hare. In the mountain forests of Ozren, Trebavac and Javornik, there are wildlife: wolf, doe deer, wild boar, fox, hare and badger. The thick set of deciduous and coniferous forests, numerous glades, meadows and pastures of Konjuh provide the survival of animals and a rich fauna. 2 They are inhabited by bears, doe deer, buck deer, chamois, grouse, wild cat, and since recently mouflon game. Pheasants, partridges, quails, hares, foxes and deer have their habitat on flat terrain along the rivers Spreča, Tinja and Brka.3 In the protected area of the old riverbed of the Spreča, its habitat has a beaver. Wading birds as well as those birds which settle or nest by water can be found along all streams. Alongside of Modrac

\footnotetext{
${ }^{1}$ PhD Senada Nezirović, Assistant Professor, Department of Geography, Faculty of Science, University of Sarajevo, Sarajevo, Bosnia and Herzegovina, e-mail: senadanezirovic@yahoo.com

${ }^{2}$ Act to designate part of Konjuh mountain as a protected landscape "Konjuh" (2009): The Government of the Tuzla Canton, Tuzla

${ }^{3}$ Public company "Forests of the Tuzla Canton" joint stock company (2015). Annual plan for the management of special hunting ground "Konjuh" for the hunting season 2015/2016, Kladanj
} 
lake are settled: red heron, coot, cormorant, grebe, great reed warbler, whiskered tern, wild duck. ${ }^{1}$ (Fig. 1.)

Considered as a complementary tourist value, the fauna enables development of hunting and enriches the tourist offer in protected areas. Seen from the tourist and geographical point of view, tourism potentials in the Tuzla Canton are part of the entire geographic area and represent a comparative advantage in its economic development, provide a good basis for a more dynamic development of hunting tourism as a factor of overall economic development.

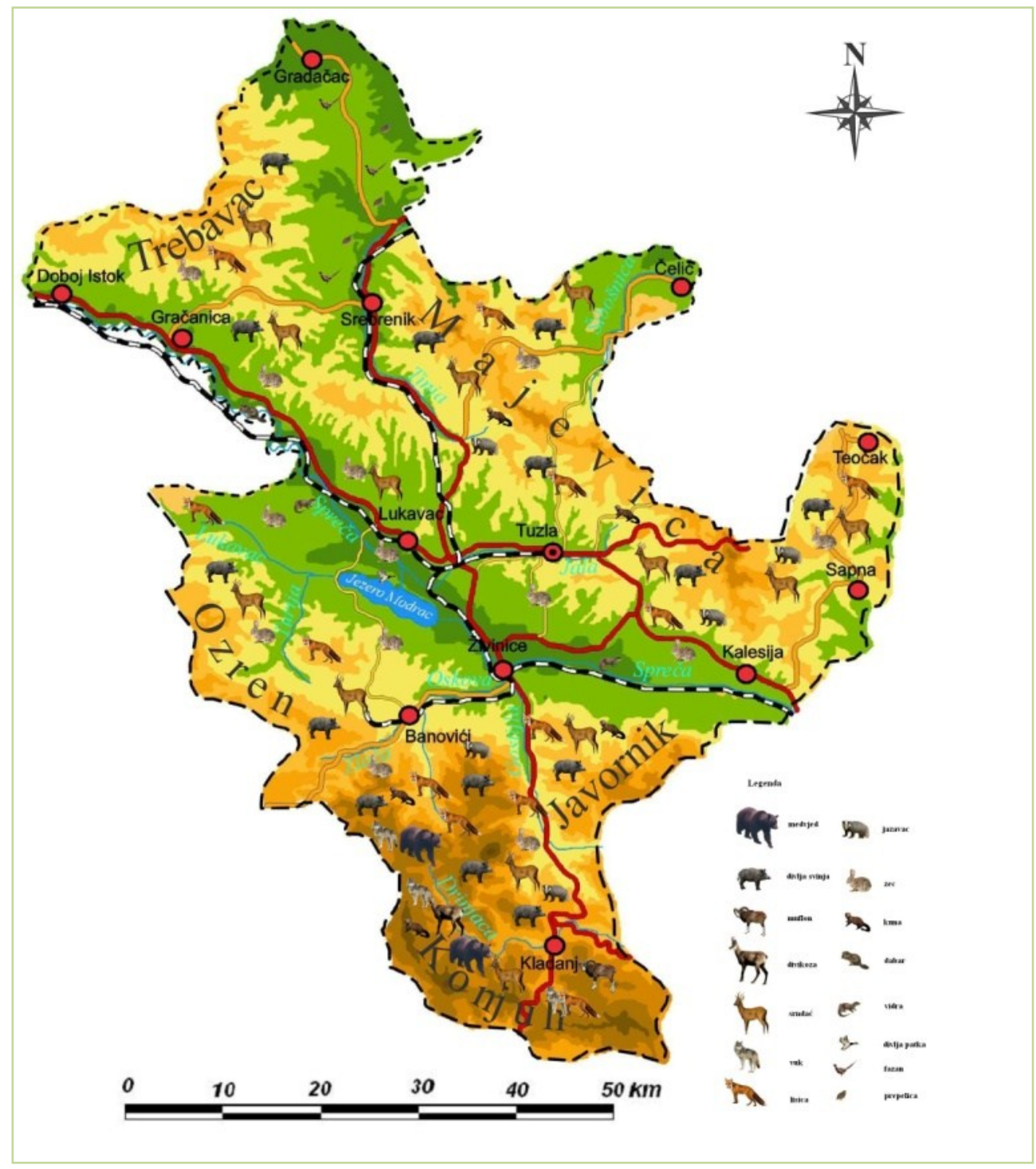

Fig. 1. The fauna in the area of the Tuzla Canton

(the map done by the author)

\footnotetext{
${ }^{1}$ Ćatović, A. (2010).Turizam in the economic structure of north-eastern Bosnia, Scientific journal Tourism 14th edition, volume 1, Novi Sad.
} 


\section{THE HUNTING GROUNDS IN THE TUZLA CANTON}

A part of natural and anthropogenic whole where ecological conditions allow production, breeding, rearing, protection, use of one or more types of game and its parts is called hunting. ${ }^{1}$ Hunting represents trapping, culling, use and collection of wildlife parts (discarded antlers, feathers, eggs). Individual hunting of big furry or feathered game and group hunting of wild boars, wolves, foxes and jackals are organized in the hunting ground. Hunting basis provide measures for management of the hunting area for at least ten hunting years.

Annual plan of management of the hunting area is determined on the basis of the structure and number of populations of wild game in the hunting area and is adopted for one hunting year. Hunting year lasts from April of the current year to the first of March of the following calendar year. ${ }^{2}$ The hunting grounds are represented by hunting production and hunting technical facilities. On the basis of habitat conditions and purpose, hunting grounds in the Tuzla Canton vary according to elevation (lowland, mountainous and highmountainous), type of game (big, small, feathered), type (mountainous and plain, hilly and mountainous with large or small game), habitat (forest, field and meadow). According to the management, hunting grounds in the area of the Tuzla Canton are divided on both social and protected (state). Social hunting grounds are managed by hunting associations whose aim is development and improvement of hunting and taking joint actions in the management of hunting grounds in the territory of the Canton. ${ }^{3}$ In the area of the Canton operates Hunting Association which gathers 14 hunting societies, one of which is from the area of Brčko District. The Alliance has more than five thousand members which makes it the biggest alliance in the Federation of Bosnia and Herzegovina. (Tab. 1).

Konjuh mountain is characterized with more mountain peaks over $1000 \mathrm{~m}$ of altitude, it has significant natural and anthropogenic values. The tourism potential of Konjuh mountain are high mountain hunting grounds.

\footnotetext{
${ }^{1}$ Newsletter of the Union of hunting organizations BiH (1997), Hunting Gazette No. 4, Sarajevo.

${ }^{2}$ Big illustrated encyclopedia of hunting, 1992: Volume II Construction Book, Belgrade

${ }^{3}$ Catalogue of Alliance of hunting societies Tuzla Canton, 2014, Tuzla
} 
Tab. 1. Social hunting grounds in the area of the Tuzla Canton

\begin{tabular}{|c|c|c|c|}
\hline \multirow{2}{*}{$\begin{array}{l}\text { Municipality/ } \\
\text { the name of } \\
\text { Hunting society }\end{array}$} & \multirow{2}{*}{$\begin{array}{l}\text { Number of } \\
\text { members }\end{array}$} & Area ha & \multirow[b]{2}{*}{ Types of game } \\
\hline & & type / altitude m & \\
\hline \multirow{2}{*}{$\begin{array}{l}\text { Banovići/ } \\
\text { Zelemboj }\end{array}$} & \multirow[t]{2}{*}{180} & 17300 & \multirow{2}{*}{$\begin{array}{l}\text { basic: black bear, wild boar, deer, } \\
\text { grouse accompanying: marten, fox, } \\
\text { wild cat, wolf. hare, wild duck }\end{array}$} \\
\hline & & hilly and mountainous $269-1125$ & \\
\hline \multirow{2}{*}{$\begin{array}{l}\text { Šibošnica-Čelić/ } \\
\text { Vjetrenik }\end{array}$} & \multirow[t]{2}{*}{515} & 22226 & \multirow[t]{2}{*}{ deer, hare, pheasant and wild boar } \\
\hline & & hilly and mountainous $138-771$ & \\
\hline \multirow{2}{*}{$\begin{array}{l}\text { Doboj Istok/ } \\
\text { "Fazanka" }\end{array}$} & \multirow[t]{2}{*}{120} & 2644 & \multirow[t]{2}{*}{ deer, hare, pheasant } \\
\hline & & plain up to 280 & \\
\hline \multirow{2}{*}{$\begin{array}{l}\text { Gradačac/ } \\
\text { Jelen }\end{array}$} & \multirow[t]{2}{*}{410} & 17430 & \multirow{2}{*}{$\begin{array}{l}\text { basic: deer, hare, pheasant } \\
\text { accompanying: quail }\end{array}$} \\
\hline & & plain and hilly $129-600$ & \\
\hline \multirow{2}{*}{$\begin{array}{l}\text { Kalesija/ } \\
\text { Spreča }\end{array}$} & \multirow[t]{2}{*}{550} & 19200 & \multirow{2}{*}{$\begin{array}{l}\text { basic: pheasant, hare, fox, marten, } \\
\text { wild cat, accompanying: wolf }\end{array}$} \\
\hline & & hilly and mountainous $220-915$ & \\
\hline \multirow{2}{*}{$\begin{array}{l}\text { Kladanj/ } \\
\text { Sokolina }\end{array}$} & \multirow[t]{2}{*}{320} & 18103 & \multirow{2}{*}{$\begin{array}{l}\text { basic: black bear, capercaillie, doe } \\
\text { deer, chamois, squirrel, hawk, owl, } \\
\text { raven, hare and pheasant. }\end{array}$} \\
\hline & & hilly and mountainous $400-1323$ & \\
\hline \multirow{2}{*}{$\begin{array}{l}\text { Lukavac/ } \\
\text { Svatovac }\end{array}$} & \multirow[t]{2}{*}{550} & 33500 & \multirow{2}{*}{$\begin{array}{l}\text { basic: hare, pheasant and doe deer, } \\
\text { wild boar } \\
\text { accompanying: wild duck, woodcock, } \\
\text { partridge }\end{array}$} \\
\hline & & plain and hilly $175-884$ & \\
\hline \multirow{2}{*}{$\begin{array}{l}\text { Sapna/ } \\
\text { Mustafa Čeketalo }\end{array}$} & \multirow[t]{2}{*}{230} & 14000 & \multirow{2}{*}{$\begin{array}{l}\text { basic: bear, buck deer, wild boar, } \\
\text { pheasant, hare, fox, cat, marten, } \\
\text { badger and a small number of } \\
\text { pheasant }\end{array}$} \\
\hline & & hilly and mountainous $147-916$ & \\
\hline Srebrenik & \multirow[t]{2}{*}{500} & 19200 & \multirow{2}{*}{$\begin{array}{l}\text { basic: deer, wild boar, pheasant, hare, } \\
\text { fox, marten. }\end{array}$} \\
\hline Majevica & & hilly and mountainous $220-915$ & \\
\hline \multirow{2}{*}{$\begin{array}{l}\text { Teočak/ } \\
\text { "K.Hajro" }\end{array}$} & \multirow[t]{2}{*}{114} & 2900 & \multirow{2}{*}{$\begin{array}{l}\text { basic: deer, hare, wild boar, } \\
\text { accompanying : fox, cat, marten, } \\
\text { badger, bear, pheasant. }\end{array}$} \\
\hline & & plain and hilly $250-675$ & \\
\hline \multirow{2}{*}{$\begin{array}{l}\text { Tuzla/ } \\
\text { Tuzla }\end{array}$} & 600 & 27152 & deer, hare, pheasant, marten, fox, \\
\hline & & hilly and mountainous $231-843$ & woodcock, wild duck and wild boar \\
\hline Živinice/ & 420 & 25.747 & basic: wild boar, hare, pheasant, \\
\hline $\begin{array}{l}\text { Toplice: } \\
\text { two hunting parts: } \\
\text { Spreča and Dubrava }\end{array}$ & & $\begin{array}{l}\text { plain and hilly } 190-300 \\
\text { hilly and mountainous } 200-1200\end{array}$ & $\begin{array}{l}\text { grouse, hazel grouse, grey partridge, } \\
\text { wild duck, accompanying: fox, wild } \\
\text { cat, white breasted marten and pine } \\
\text { marten, wild cat, wolf, weasel, } \\
\text { badger, crow, magpie, hawk, common } \\
\text { snipe and woodcock, quail and } \\
\text { common wood pigeon }\end{array}$ \\
\hline Gornji Rahić(15km) & 248 & 22000 & basic: pheasant, quail, partridge, hare, \\
\hline $\begin{array}{l}\text { Brčko/ } \\
\text { Fazani } 1946\end{array}$ & & plain $169-260$ & $\begin{array}{l}\text { deer, wild boar, accompanying: fox, } \\
\text { marten, and badger, wild duck, } \\
\text { woodcock, common wood pigeon, } \\
\text { Eurasian collareddove }\end{array}$ \\
\hline
\end{tabular}

Source: table done by the author based on data from the Catalogue of Alliance of hunting societies Tuzla Canton

\section{The high mountain hunting ground Sokolina}

The high mountain hunting ground Sokolina spreads across the slopes of mountains Konjuh and Javor. The user of the hunting ground is the Association of citizens Hunting society "Sokolina". It is of an open type and it borders with the Special hunting ground 
Konjuh. In the hunting ground Sokolina, the protected game species are: brown bear, capercaillie grouse, doe deer, chamois, squirrel, hawk, owl, raven, hare and pheasant. Bears are protected by a closed season. Estimated hunting productive area for bear is 12.377 hectares, the capacity is 14 individuals. Deer inhabit the whole area of the hunting ground, it belong to the second bonitet (quality), hunting ground capacity for deer is 40 indivduals per 1.000 hectares. Chamois settle 531 ha of hunting productive area of the second quality, the capacity for this type of game is 37 individuals, they inhabit southern parts of the hunting grounds.

In the hunting ground, there are hunting breeding facilities: feeding facilities 114, salt licks for chamois 36 , watering places 31 , salt licks for deer game 12, hunting and technical facilities: hunting lodges and huts 10 , bunkers, shooting stads and watch towers 5 , high shooting stads of closed type 13, high shooting stads of open type 15, hunting trails $33 .{ }^{1}$ (Tab. 2).

Tab. 2. Hunting society Sokolina, hunting breeding and technical facilities

\begin{tabular}{|c|c|c|c|c|c|c|c|}
\hline & \multicolumn{6}{|c|}{ local area } & \multirow[b]{2}{*}{ Total } \\
\hline & Kladanj & Starič & Tuholj & Brateljeviči & Stupari & Tarevo & \\
\hline \multicolumn{8}{|c|}{ Hunting and breeding facilities } \\
\hline Type of building & 10 & 5 & 3 & 4 & 4 & 7 & 33 \\
\hline Feeding facilities & 24 & 19 & 17 & 16 & 19 & 19 & 114 \\
\hline $\begin{array}{l}\text { Salt licks for } \\
\text { chamois }\end{array}$ & 6 & 6 & 6 & 6 & 6 & 6 & 36 \\
\hline Watering places & 7 & 5 & 5 & 5 & 4 & 5 & 31 \\
\hline $\begin{array}{l}\text { Salt licks for deer } \\
\text { game }\end{array}$ & - & 12 & - & - & - & - & 12 \\
\hline \multicolumn{8}{|c|}{ Hunting and technical facilities } \\
\hline $\begin{array}{l}\text { Hunting lodges } \\
\text { and huts }\end{array}$ & 4 & 2 & 1 & 1 & 1 & 1 & 10 \\
\hline $\begin{array}{l}\text { Shooting stads } \\
\text { and watch towers }\end{array}$ & - & 1 & 1 & 2 & - & 1 & 5 \\
\hline $\begin{array}{l}\text { High shooting } \\
\text { stads of closed } \\
\text { type }\end{array}$ & 4 & 2 & 2 & 2 & 2 & 1 & 13 \\
\hline $\begin{array}{l}\text { High shooting } \\
\text { stads of open type }\end{array}$ & 4 & 2 & 3 & 2 & 2 & 2 & 15 \\
\hline Hunting trails & 7 & 5 & 5 & 5 & 6 & 5 & 33 \\
\hline
\end{tabular}

Source: Hunting society “Sokolina“ 2007, Hunting economic basis 2007-2016, Kladanj

\section{The special hunting ground Konjuh}

The special hunting ground Konjuh is located in the central part of the massif of Konjuh mountain which belongs to the central Dinaric mountain system. Spatially, it is located in the northern part of the municipality of Kladanj $(7.240 \mathrm{ha})$, the western part of the municipality Olovo ( $821 \mathrm{ha})$, the southwestern part of the municipality Banovići (2.617 ha), the south-eastern part of the municipality of Živinice (2.647 ha) within the parts of the forest-economic areas "Konjuh", "Sprečko " and "Olovska". Altitude of the hunting ground ranges from 300 to 1328 meters. $^{2}$ It borders with the followong hunting grounds: "Sokolina", "Toplica“, "Zelemboj" and "Tetrijeb". Area of the hunting ground is 13.325

\footnotetext{
${ }^{1}$ Hunting society "Sokolina“" 2007: Hunting economic basis 2007-2016, Kladanj

${ }^{2}$ Public company "Forests of the Tuzla Canton" joint stock company (2015). Annual plan for the management of special hunting ground "Konjuh" for the hunting season 2015/2016, Kladanj
} 
ha, which is characterized by two hunting parts: Drinjača (6.202 ha) and Oskova (6.450 ha). ${ }^{1}$ Hunting grounds are characterized by steep slopes, sharp ridges, narrow valleys and mountain peaks over $1000 \mathrm{~m}$, in which there are numerous springs and river basins of the Oskova, Litva, Gostilja and Drinjača. The area of the hunting ground is covered with mixed forests, intersected by meadows and pastures, which represents favorable conditions for the reproduction of wild animals.

The hunting area is inhabited with protected, accompanying and unprotected species of wildlife. Protected breeding species of wildlife are: the brown bear, deer, wild boar and grouse. The brown bear is a rare species of wildlife, it inhabits the entire area of the hunting ground, especially the central parts. According to the hunting records, there are 6 individuals inhabiting the hunting ground. Doe deer inhabit almost the entire area of the hunting ground, the capacity of individuals is 116 . Wild boars inhabit the entire area of the hunting ground, there are 78 individuals. Grouses inhabit the southwestern parts of the hunting ground, the capacity is 26 individuals. $^{2}$

The accompanying game species are: hare, hazel grouse, wild pigeon, Eurasian collareddove, hawk and squirrel. The unprotected species are: wild boar, wild cat, badger, skunk, pine marten, white breasted marten, wolf, feathered game, crow, magpie and jay. In the hunting ground, there are hunting breeding facilities: solid food feeding stations 17, feeding stations for bears and wild boars 5, salt licks 98, water stations 22, mad baths 66; hunting and technical facilities: hunting lodges 2 , hunting huts 2 , high shooting stad of closed type 5, high shooting stad of open type 5, bunker, shooting stad and watch tower 5 , eaves 7 , food warehouse 2. (Tab. 3)

Tab. 3. The special hunting ground Konjuh, hunting breeding and technical facilities 2015/2016

\begin{tabular}{|l|r|l|c|}
\hline Hunting and technical facilities & & Hunting breeding facilities & total \\
\hline Hunting lodges & 2 & Solid food feeding stations & 17 \\
\hline Hunting huts & 2 & Feeding stations for bears and wild boars & 5 \\
\hline High shooting stad of closed type & 5 & Licks & 98 \\
\hline Bunker, shooting stad and watch tower & 5 & Water stations & 22 \\
\hline High shooting stad of open type & 5 & Mad baths & 66 \\
\hline Hunting trails & 70 & & \\
\hline Eaves & 7 & & \\
\hline Food warehouse & 2 & & \\
\hline
\end{tabular}

Source: Public company "Forests of the Tuzla Canton" joint stock company (2015). Annual plan for the management of special hunting ground "Konjuh" for the hunting season 2015/2016, Kladanj

Based on this review, it can be estimated that in the special hunting ground "Konjuh" there are enough hunting facilities which should be regularly maintained within the planned period and with the obligation of recovery of destroyed hunting lodges. There is a hunting lodge with 20 beds at the hunting ground to accommodate guests in the Zlaća as well as a large number of accommodation facilities at the Zlaća hotel, which offers the possibility of accepting visitors and hunt enthusiasts.

\footnotetext{
${ }^{1}$ Act to designate part of Konjuh mountain as a protected landscape "Konjuh" (2009): The Government of the Tuzla Canton, Tuzla

${ }^{2}$ Public company "Forests of the Tuzla Canton" joint stock company (2015). Annual plan for the management of special hunting ground "Konjuh" for the hunting season 2015/2016, Kladanj
} 


\section{THE POSSIBILITY OF DEVELOPMENT OF HUNTING TOURISM IN THE TUZLA CANTON}

Hunting tourism can be defined as a form of provision of services to people because of wild game culling or wildlife observation and photography with a certain fee. Besides, hunting is an important form of sports and recreational activities of hunters, and is useful for the development of the noble game species. Hunting grounds of the Tuzla Canton have favorable climate, vast areas of forest and mountain meadows, which provides conditions for development of hunting and recreational tourism. This is especially true of the hunting ground of Konjuh mountain.

In the hunting ground Sokolina, there is planned breeding and sanitary culling for breeding species of wild animals, and after reaching full capacity, culling can take place as specified by annual plan for the period 2014-2016. ${ }^{1}$ (Tab. 4.) Signaling signs, road signs, movement prohibition signs, signs for location of hunting facilities and signs with basic details of the hunting ground are missing in the hunting ground.The construction and expansion of hunting facilities has been planned that will enable the development of a number of specimens of deer, wild boar, brown bear and grouse.

Tab. 4. Dynamics of game culling in the hunting ground Sokolina for the period 20142016.

\begin{tabular}{|c|c|c|c|c|c|c|c|c|c|c|c|c|c|c|}
\hline \multirow{2}{*}{$\begin{array}{l}\text { Annual } \\
\text { /game } \\
\text { culling }\end{array}$} & \multicolumn{3}{|c|}{ Doe deer } & \multicolumn{3}{|c|}{ Chamois } & \multicolumn{3}{|c|}{ Wild boar } & \multicolumn{3}{|l|}{ Bear } & \multirow[t]{2}{*}{ Grouse } & \multirow[t]{2}{*}{ Hare } \\
\hline & mature & young & total & mature & young & total & Mature & young & total & mature & young & total & & \\
\hline 2014 & 36 & 14 & 50 & 2 & 1 & 3 & 17 & 35 & 52 & 3 & - & 3 & 6 & 136 \\
\hline 2015 & 36 & 14 & 50 & 3 & 1 & 4 & 17 & 35 & 52 & 3 & - & 3 & 6 & 136 \\
\hline 2016 & 36 & 14 & 50 & 3 & 1 & 4 & 17 & 35 & 52 & 3 & - & 3 & 6 & 136 \\
\hline
\end{tabular}

Source: Hunting society "Sokolina“ 2007, Hunting economic basis 2007-2016, Kladanj

The protected hunting ground Konjuh, besides gun hunting, offers the possibility of observing, recording and photographing of wildlife, which is becoming increasingly popular motive for the population to go from urban areas to nature in order to experience hunting. The nutrition and health control of the wildlife in winter is done in the hunting ground according to the development plan. Use of the game is done through the game culling according to the hunting calendar. The main purpose of the Special hunting ground is growing, protection and use of productive populations of wildlife, considering the special conditions of the habitat of rare, very rare and valuable species of wildlife, a certain degree of intensity of hunting management and maintenance of the tolerable damage from wild animals in forest and agricultural areas, and that with the economic function also have the function of protecting and preserving biological and ecological balance of natural habitats of wildlife, and maintaining biological balance and diversity of the gene pool of autochthonous species. The following table shows the capacity of the hunting ground. (Tab. 5.)

\footnotetext{
${ }^{1}$ Hunting society "Sokolina“ 2007: Hunting economic basis 2007-2016, Kladanj
} 
Tab. 5. The capacity of the Konjuh hunting ground for the hunting season 2015/16.

\begin{tabular}{|l|l|l|l|}
\hline Type of game & hunting productive area /ha & Capacity & Spring condition \\
\hline Doe deer & 11.500 & 400 & 106 \\
\hline Bear & 12.000 & 12 & 8 \\
\hline Capercaillie & 3000 & 40 & 26 \\
\hline Wild boar & 12000 & 112 & 69 \\
\hline
\end{tabular}

Source: Public company "Forests of the Tuzla Canton" joint stock company (2015).Annual plan for the management of special hunting ground "Konjuh" for the hunting season 2015/2016, Kladanj

The special hunting ground Konjuh owns also accommodation facilities, weapons for rent, terrain vehicles, optical devices and cameras. Maintenance, administration and good organization in the rich hunting grounds, allows the use of resources for the purpose of recreation. The fauna in the protected area of Konjuh helps enriching the tourist offer. Special attention to the hunting grounds attract rare species of wildlife: chamois, fallow deer, mouflon, grouse. ${ }^{1}$

Plain-marsh hunting grounds at small and feathered game in the valley of the Spreča also have the possibilities for development of hunting tourism. The hunting societies Svatovac and Toplice exit to Modrac lake by a larger part of their territory. ${ }^{2}$ The hunting society Fazani 1946 stretches along the border of territory of the Tuzla Canton, $15 \mathrm{~km}$ from the town of Brčko. It is one of the major hunting grounds with a long tradition, it was active under the name of "Fazan" Brčko. The development program has the aim of organizing hunting for foreign hunters for quail, pike, common wood pigeon and wild duck. It has six hunting lodges, two hunting huts, a big shooting stad for hunting and wildlife observation, and two eaves.

\section{CONCLUSION}

In the hunting and economic grounds in the area of the Tuzla Canton, economically valuable game preserves can be grown and sustainably used. The hunting grounds should take greater activity in the organization, sustainable management and protection of autochthonous species of wild animals: bears, chamois, grouse, hazel grouse, quail, grey partridge as well as the introduction of new game.

In reforestation, there should make a selection of plants that bear fruit or seeds that wild game like to eat, such as oak, wild cherry, pear, apple and sweet chestnut (Castanea sativa). By the act of protection of the precious species of wildlife, action should be taken on the restoration of hunting areas regarding breeding and development of hunting grounds, and the increase of repopulating the wildlife in their indigenous habitats. To increase foreign tourist traffic in the hunting areas, one should build facilities for accommodation, rest, refreshment and food supply for the nature and hunting lovers, and enrich offer of culinary specialties specially adapted to the ethnic characteristics of this region, such as dishes under the bell and plum brandy. The only way for the Tuzla Canton to increase the influx of visitors and achieve economic benefits is to improve the existing and build new modern accommodation capacities.

\footnotetext{
${ }^{1}$ Act to designate part of Konjuh mountain as a protected landscape "Konjuh" (2009): The Government of the Tuzla Canton, Tuzla

${ }^{2}$ Official Gazette TK 9/06 (2008): Spatial plan for Tuzla Canton (2005-2015), Tuzla
} 


\section{REFERENCES}

1. Act to designate part of Konjuh mountain as a protected landscape "Konjuh" (2009): The Government of the Tuzla Canton, Tuzla

2. Public company "Forests of the Tuzla Canton" joint stock company (2015) . Annual plan for the management of special hunting ground "Konjuh" for the hunting season 2015/2016, Kladanj

3. Ćatović, A. (2010). Tourism in the economic structure of north-eastern Bosnia, Scientific journal Tourism 14th edition, volume 1,NoviSad

4. Big illustrated encyclopedia of hunting, Volume II (1992). ConstructionBook, Belgrade

5. Catalogue of Alliance of hunting societies Tuzla Canton (2014), Tuzla

6. Public company "Forests of the Tuzla Canton" joint stock company (2015) . Annual plan for the management of special hunting ground "Konjuh" for the hunting season 2015/2016, Kladanj

7. Hunting basis of hunting societies of the Tuzla Canton

8. Official Gazette TK 9/06 (2008): Spatial plan for Tuzla Canton (2005-2015), Tuzla

9. Newsletter of the Union of hunting organizations Bosnia and Herzegovina (1997). Hunting Gazette No. 4, Sarajevo 